\title{
ПРОБЛЕМЫ ПРИМЕНЕНИЯ РЕЙТИНГОВ ДЛЯ ОЦЕНКИ КАЧЕСТВА ВЫСШЕГО ОБРАЗОВАНИЯ
}

\author{
Никонова М.А.
}

Востребованность различных рейтингов, в том числе и для оченки качества высшего образования, как в вузах за рубежом, так и в российских, приводит к тому, что качество образования отходит на второй план, а на первый план выходит повышение показателей, входящие в рейтинги. Несмотря на то, что применимость рейтингов для вузов России вызывает много вопросов, до сих пор вузы стремятся в них войти, что, несомненно, сказывается на изменении выстего образования в стране.

DOI: $10.20537 /$ mce2021 econ08

Ведущими мировыми рейтингами вузов являются QS, THE и ARWU. Необходимо отметить, что данные рейтинги разрабатывались в интересах определенных стран (THE и QS - США и Великобритании, ARWU - Китая). Это находит отражение в числе вузов, входящих в TOP-100 данных рейтингов. Так, например, в рейтинге QS основными странами, чьи вузы входят в рейтинг, являются США и Великобритания. Далее, с большим отрывом идут Австралия, Япония, Нидерланды, Германия, Канада и др.

Именно поэтому указанные рейтинги малоприменимы для российских вузов. Однако это не останавливает последних в «погоне» за показателями рейтингов и является одной из негативных причин трансформации подходов к высшему образованию.

Отметим, что в работах [1-5] проводилось исследование международных рейтингов и возможности их применения для оценки эффективности российских вузов. В данной работе не только показана невозможность применения международных рейтингов для оценки мест российских вузов, но также проведен анализ влияния отдельных показателей (входящих в рейтинг QS) на итоговое место ведущих российских вузов в международ- 
ном рейтинге (на примере рейтинга QS), а также проанализирован рейтинг RAEX в качестве возможной альтернативы международным рейтингам.

Поскольку рейтинги (QS, ARWU и THE) были разработаны с ориентацией на определенные вузы, это сказалось на показателях, которые они оценивают. Так, в рейтинге QS [6] основными составляющими итоговой оценки являются следующие: $40 \%$ - экспертная оценка академической репутации вуза, $20 \%$ - соотношение профессорскопреподавательского состава вуза и численности обучающихся, 20\% индекс цитирования научных работ преподавательского состава вуза по отношению к численности преподавательского состава и $10 \%$ - репутация вуза среди работодателей, которая получается опросным методом.

Показатели рейтинга THE похожи на показатели рейтинга QS, что связано с тем, что первоначально они были объединены в один рейтинг (до 2010 г.). К основным показателям рейтинга ТНЕ относятся: общая цитируемость научных публикаций, нормализованная относительно разных областей исследований $(32.5 \%)$; научная репутация университета в определенных областях (19.5\%); академическая репутация университета, включая научную деятельность и качество образования (15\%).

K основным показателям рейтинга ARWU относятся: число сотрудников-лауреатов Нобелевской или Филдсовской премии (20\%); число наиболее часто цитируемых исследователей в любых предметных областях (20\%); число статей, опубликованных в журналах Nature и Science (20\%); число статей, проиндексированных в Science Citation Index — Expanded и Social Sciences Citation Index (20\%).

Таким образом, довольно высокую долю в указанных рейтингах составляет уровень цитирований печатных работ преподавателей вузов. Однако при расчете рейтинга учитываются не все публикации, а публикации в узком круге журналов, например, Nature и Science, или индексация статей Science Citation Index - Expanded и Social Sciences Citation Index. B силу недостаточного (а порой и практически отсутствия) интереса данных изданий к российским исследованиям, особенно в социогуманитарной сфере, публикации в таких журналах затруднительны. Исключение отчасти составляют исследования в области математики, программирования, инжиниринга, биотехнологии и др. Это является одной из причин относительно низких мест российских вузов в указанных рейтингах.

В исследовании был проведен анализ мест российских вузов в указанных рейтингах. Для этого использовалась регрессионная модель вида 


$$
y=\sum_{i} a_{i} x_{i}+b
$$

где $y$ - место в рейтинге, $b$ - свободный член, $x_{i}$ - показатель рейтинга: $\mathrm{x} 1$ - академическая репутация, $\mathrm{x}_{2}$ - репутация вуза среди работодателей, х3 - соотношение преподавателей к студентам,

$\mathrm{X} 4$ - соотношение иностранных преподавателей к общей численности преподавателей, Х5 - доля иностранных студентов, $\mathrm{x}_{6}$ - цитируемость (индекс цитирования научных работ преподавательского состава вуза по отношению к численности преподавательского состава).

Исследование проводилось по данным рейтинга QS [6]. Результаты моделирования приведены в табл. 1.

Таблица 1. Результаты оценки параметров модели (1) для определения места вуза в рейтинге QS.

\begin{tabular}{|l|c|c|}
\hline Фактор & Коэффициент & t-статистика \\
\hline Свободный член & 297.58 & 44.15 \\
\hline академическая репутация $\left(\mathrm{x}_{1}\right)$ & -2.16 & -17.64 \\
\hline репутация вуза среди работодателей $\left(\mathrm{x}_{2}\right)$ & -0.34 & -6.66 \\
\hline соотношение преподавателей к студентам $\left(\mathrm{x}_{3}\right)$ & -0.44 & -19.84 \\
\hline $\begin{array}{l}\text { соотношение иностранных преподавателей } \\
\text { общей численности преподавателей }\left(\mathrm{x}_{4}\right)\end{array}$ & -0.06 & -2.59 \\
\hline доля иностранных студентов $\left(\mathrm{x}_{5}\right)$ & -0.20 & -7.24 \\
\hline цитируемость $\left(\mathrm{x}_{6}\right)$ & -0.49 & -15.22 \\
\hline $\mathrm{R}^{2}$ & \multicolumn{2}{|c|}{0.94} \\
\hline
\end{tabular}

Таким образом, наиболее значимыми факторами рейтинга QS являются цитируемость, соотношение преподавателей к студентам и академическая репутация вуза.

В 2021 г. МГУ был единственным российским вузом, который вошел в TOP-100 рейтинга QS. Он занял 74 место. Остальные вузы Санкт-Петербургский (СПбГУ), Новосибирский (НГУ), Томский (ТГУ) государственные университеты, МФТИ, МГТУ им. Баумана и Высшая школа экономики - оказались в третьей сотне вузов этого рейтинга.

В табл. 2 приведены рейтинговые места этих вузов и их баллы по отдельным позициям рейтинга QS (по данным [6]). 
Таким образом, можно увидеть, что из трех наиболее значимых (с точки зрения составления рейтинга) показателей российские вузы высоко оцениваются только по соотношению численности преподавателей к студентам (баллы почти у всех вузов превышает 90). Академическая репутация относительно высокая только у МГУ (77.3 из возможного максимума в 100 баллов). Показатель цитируемости очень низкий (условными исключениями можно назвать Новосибирский государственный университет и Физтех, где оценка этого критерия превысила 10 баллов, но меньше 20 баллов).

Отметим, что самые низкие оценки российские вузы получили по уровню цитируемости и соотношению иностранных преподавателей к общей численности преподавателей. Поэтому интерес представляет место российских вузов в рейтинге QS без учета этих показателей (см. табл. 3).

Как показал расчет, без учета указанных выше показателей МГУ вошел бы в первые 30 вузов по рейтингу QS. Остальные вузы переместились бы из третьей сотни вузов во вторую (за исключением ВШЭ). Можно отметить, что место Томского государственного университета было бы значительно выше (он смог бы занять 111 место), обогнав Санкт-Петербургский и Новосибирский государственные университеты.

В качестве альтернативы мировым рейтингам вузов в России рассчитывается Рейтинг лучших вузов России RAEX-100 [7]. Вузы оцениваются по следующим группам интегральных факторов: условия для получения качественного образования в вузе, уровень востребованности работодателями выпускников, уровень научно-исследовательской деятельности вуза. Можно отметить пересечение по факторам с мировыми рейтингами. Так, в рейтинге RAEX оценивается доля иностранных студентов очной формы обучения; оценка работодателями качества знаний и навыков выпускников; количество публикаций за последние пять лет в научных журналах, индексируемых в зарубежных базах данных, на одного научно-педагогического работника; количество цитирований статей, изданных за последние пять лет, в среднем на одну статью, согласно зарубежным базам данных.

В табл. 4 приведены данные рейтинга RAEX [7] по рассматриваемым в работе вузам. Как видно из табл. 4, порядок вузов несколько изменился: Физтех оказался на 2 месте (хотя согласно оценке рейтинга QS этот вуз был в перечне российских вузов шестым), ВШЭ также поднялся (в рейтинге QS он был седьмым среди российских вузов, в рейтинге RAEX - четвертый). 
Анализ и моделирование экономических и сочиальных прочессов - МКО - 2021 Analysis and modeling of economic and social processes - MCE - 2021

Таблица 2. Оценки места российских вузов в рейтинге QS в 2021 г. (по данным [6]).

\begin{tabular}{|l|l|l|l|l|l|l|l|}
\hline & МГУ & СПбГУ & НГУ & ТГУ & МФТИ & МГТУ & ВШЭ \\
\hline Место в рейтинге & 74 & 225 & 228 & 250 & 281 & 282 & 298 \\
\hline Общий балл & 65.9 & 39.9 & 39.4 & 37.7 & 35.3 & 35.2 & 34.4 \\
\hline $\begin{array}{l}\text { академическая ре- } \\
\text { путация }\end{array}$ & 77.3 & 41.2 & 28.8 & 21.7 & 15.7 & 21.6 & 26.1 \\
\hline $\begin{array}{l}\text { репутация вуза сре- } \\
\text { ди работодателей }\end{array}$ & 82.8 & 29.2 & 21.3 & 15.1 & 27.9 & 48.9 & 32.8 \\
\hline $\begin{array}{l}\text { соотношение пре- } \\
\text { подавателей к сту- } \\
\text { дентам } 99.8\end{array}$ & 83.3 & 94.7 & 99.9 & 97.7 & 100 & 94 \\
\hline $\begin{array}{l}\text { соотношение ино- } \\
\text { странных препода- } \\
\text { вателей к общей } \\
\text { численности препо- } \\
\text { давателей }\end{array}$ & 20.1 & 5.9 & 9 & 29.1 & 32 & 11 & 8.1 \\
\hline $\begin{array}{l}\text { доля иностранных } \\
\text { студентов }\end{array}$ & 76.8 & 36.8 & 47.2 & 93.4 & 42.4 & 11.5 & 17 \\
\hline цитируемость & 7.4 & 7.2 & 18.9 & 6.1 & 13.8 & 1.5 & 2.2 \\
\hline
\end{tabular}

Таблица 3. Изменение места российских вузов в рейтинге QS (не учитывая уровень цитируемости и соотношение иностранных преподавателей к общей численности преподавателей, по данным [6]).

\begin{tabular}{|l|l|l|l|l|l|l|l|}
\hline & МГУ & СПбГУ & НГУ & ТГУ & МФТИ & МГТУ & ВШЭ \\
\hline $\begin{array}{l}\text { Место в рей- } \\
\text { тинге QS }\end{array}$ & 74 & 225 & 228 & 250 & 281 & 282 & 298 \\
\hline $\begin{array}{l}\text { Место в рей- } \\
\text { тинге QS без } \\
\text { учета двух по- } \\
\text { казателей }\end{array}$ & 164 & 162 & 111 & 179 & 184 & 208 \\
\hline Общий балл & 65.9 & 39.9 & 39.4 & 37.7 & 35.3 & 35.2 & 34.4 \\
\hline $\begin{array}{l}\text { Общий балл } \\
\text { без учета двух } \\
\text { показателей }\end{array}$ & 84.18 & 47.63 & 48 & 57.53 & 45.93 & 45.5 & 42.48 \\
\hline
\end{tabular}


Таблица 4. Места вузов в рейтинге RAEX-2021 (по данным [7]).

\begin{tabular}{|l|c|c|c|c|}
\hline Вуз & $\begin{array}{l}\text { Место в } \\
\text { рейтинге }\end{array}$ & $\begin{array}{l}\text { Условия для по- } \\
\text { лучения каче- } \\
\text { ственного обра- } \\
\text { зования, ранг }\end{array}$ & $\begin{array}{l}\text { Уровень востре- } \\
\text { бованности вы- } \\
\text { пускников рабо- } \\
\text { тодателями, ранг }\end{array}$ & $\begin{array}{l}\text { Уровень научно- } \\
\text { исследователь- } \\
\text { ской деятельно- } \\
\text { сти, ранг }\end{array}$ \\
\hline МГУ & 1 & 1 & 1 & 1 \\
\hline СПбГУ & 4 & 3 & 12 & 7 \\
\hline НГУ & 11 & 10 & 31 & 3 \\
\hline ТГУ & 15 & 11 & 7 & 2 \\
\hline МФТИ & 2 & 2 & 10 & 12 \\
\hline МГТУ & 7 & 12 & 2 & 11 \\
\hline ВШЭ & 5 & 6 & & \\
\hline
\end{tabular}

Таким образом, составление рейтингов позволяет вузам выделить слабые стороны. Однако стремление «подняться» в рейтинге может привести к искусственному повышению места, что, в свою очередь, может сказаться на качестве высшего образования. Так, например, увеличение числа приглашенных иностранных преподавателей (речь не идет о ведущих ученых) не является отражением повышения качества высшего образования. В то же время повышение публикационной активности при неизменной академической нагрузке может негативно сказаться на качестве публикаций.

\section{СПИСОК ЛИТЕРАТУРЫ}

1. Варшавский А.Е., Комкина Т.А. Проблемы объективности международных рейтингов университетов // Вестник университета. 2011. № 3. С. 103-111.

2. Варшавский A.E., Комкина T.A. Анализ двух основных рейтингов университетов // Прикладная эконометрика. 2011. № 3 (23). С. 57-78.

3. Стукалова И.Б. Конкурентоспособность российских университетов и академические рейтинги // Современное образование. 2019. №2. С. 1-7.

4. Шаститко А.Е., Зюбина А.Л. Управление экономическими исследованиями в российских вузах: наукометрия и международные рейтинги // Мир новой экономики. 2019. №3. С. 112-126.

5. Никонова М.А. Влияние мировых рейтингов на трансформацию российского высшего образования и сферы НИОКР // Производство, наука и образование в эпоху трансформаций: Россия в [де]глобализирующемся мире / 
Сборник материалов VI Международного конгресса. Институт нового индустриального развития имени С.Ю. Витте; Конгресс работников образования, науки, культуры и техники (КРОН). Москва, 2020. С. 274-279.

6. QS World University Rankings. URL:

https://www.topuniversities.com/university-rankings/world-universityrankings/2021

7. Топ-100 вузов России. URL: https://raex-

rr.com/education/universities/rating_of_universities_of_russia\#table

\section{PROBLEMS OF USING RATINGS TO ASSESS THE QUALITY OF HIGHER EDUCATION}

\section{Nikonova M.A.}

The demand for various ratings, including those created for assessing the quality of higher education, both in universities abroad and in Russia, causes that the quality of education fades into the background while ratings' indicators growth comes to the fore. Despite the fact that the applicability of the rankings for Russian universities raises many questions, universities still strive to enter them, which undoubtedly affects the change of higher education quality in our country. 